\title{
TTR
}

Traduction, terminologie, re?daction

\section{Jean Boase-Beier and Michael Holman (eds.). The Practices of Literary Translation : Constraints and Creativity. St. Jerome Publishing, 1999, 173 p.}

\section{Jane Koustas}

Volume 12, numéro 2, 2e semestre 1999

Poésie, cognition, traduction II - Autour d'un poème de W. H. Auden

Poetry, Cognition, Translation II — On a Poem by W. H. Auden

URI : https://id.erudit.org/iderudit/037379ar

DOI : https://doi.org/10.7202/037379ar

Aller au sommaire du numéro

Éditeur(s)

Association canadienne de traductologie

ISSN

0835-8443 (imprimé)

1708-2188 (numérique)

Découvrir la revue

Citer ce compte rendu

Koustas, J. (1999). Compte rendu de [Jean Boase-Beier and Michael Holman (eds.). The Practices of Literary Translation: Constraints and Creativity. St. Jerome Publishing, 1999, 173 p.] TTR, 12(2), 189-192.

https://doi.org/10.7202/037379ar d'utilisation que vous pouvez consulter en ligne.

https://apropos.erudit.org/fr/usagers/politique-dutilisation/ 


\section{COMPTES RENDUS}

Jean Boase-Beier and Michael Holman (eds.). The Practices of Literary Translation: Constraints and Creativity. St. Jerome Publishing, 1999, 173 p.

In this collection of ten essays, the contributors address the fundamental question of the status of the translator as an author of an "original" work, rewrite or not. Forcibly, this posits once again the ageold fidelity dilemma, albeit in a somewhat different light. In the introduction, the editors state that the creativity of all writers, including translators is "constrained" by political, social, poetic and linguistic norms. In sum, one can ask, "Is the writer completely free to translate reality as he or she wants?" (4). This volume considers the relationship between the creative drive of the writer and the creativity of the translator and considers the constraints experienced by both.

The articles can be divided into two major categories, those that deal with internal "constraints", primarily of a linguistic or poetic nature, and those that discuss censorship, or "external" constraints. In "Baudelaire and the Alchemy of Translation", Emily Salines considers Baudelaire's different approaches to translation and the challenges imposed by the text. She examines various stages of Baudelaire's translation activity considering it as a bridge between translation and creation. The alchemical metaphor, used by Baudelaire himself, suggests unity in his literary activity and, the author concludes, is a "proof of the fallacy of a distinction between translation and creation in his corpus" (29). Phyllis Gaffney's study, "The achieve of, the mastery of the thing! Pierre Leyris's Verse Translations of Gerard Manley Hopkins" is as well corpus centred. The author identifies some of the morphosyntactic, lexical and rhythmical challenges of Hopkin's poetry and discusses the translator's handling of these difficulties. She concentrates in particular on "Spring and Fall" examining the genesis of the translation, attributing its success to the translator's natural talents, namely "a highly receptive ear, an exceptional sensitivity to words, their origins and contexts, and finally an intuitive sixth sense which leaves the creative mind open to the subconscious" (58). Jennifer Coates' article, "Changing Horses : Nabokov and Translation" deals with the dilemma of the writer/translator. Vladimir Nabokov, the notorious author of Lolita, produced what was judged to be a somewhat leaden translation of Aleksandr Pushkin's Eugene 
Onegin: accompanied by three volumes of meticulous commentary, the translation was deliberately literal. Coates explains Nabokov's translation, which reflected, in fact, his profound respect for Pushkin, through the study of Nabokov's own literary career both in Russia and America. Hers is a well researched, engaging account of a famous writer/translator and an interesting exploration of the way in which the translator's opinion of the author influences translation technique. Juan J. Zaro in "Moratín's Translation of Hamlet (1798) : A Study of the Paratexts" considers as well the translator's commentary. In this case, the translator/playwright, Leandro Fernández de Moratín, comments on the play itself, notably on words and expressions which are "inappropriate to tragic sublimity", the appropriateness of time, space and action and the absence of rigour and verisimilitude. He includes as well notes on England and the English, on his admiration for Shakespeare, on previous translations, improper language and specific translation problems and adds comments from other experts. Zaro concludes that this extensive commentary stems from the tension between the translator/playwright's own creative style and his profound admiration for the author translated.

Two articles bridge the division between studies on external and internal constraints. In Cormac O Cuilleanáin's "Not in Front of the Servants : Forms of Bowdlerism and Censorship in Translation" and Claudine Tourniaire's "Bilingual Translation as a Re-creation of the Censored Text : Rhea Galanaki in English and French", the authors deal with translating the unacceptable. Ó Cuilleanáin discusses translations of Voltaire, Boccaccio, Shakespeare, Brian Merriman, O'Faolain, Vizinczey, e.e. cummings and Rodari illustrating cases where translators were confronted with obscenities. The title is based on Thomas Bowdler's puritanical translation "The Family Shakespeare". The author identifies various strategies used by translators, such as leaving the offensive passages in the target language, translating them into a third language or, as in the case of Bowdler, simply excising the text. Ó Cuilleanain successfully illustrates the link between translation and censorship in an interesting article that discusses a wide range of genres and languages. Tourniaire's article deals with a similar problem but in the opposite sense : the concern here is not, as in the above, that of disguising the censored passages for the target audience, but, instead, that of revealing offensive material that was coded in the source language to avoid the censors' wrath. Writing immediately after the military dictatorship in Greece, Galanki was forced to practice self-censorship and thus, as she 
states herself, wrote very "secret" poems. Tourniaire's article discusses her own efforts as a translator to strike a balance between respecting the constraints imposed on the original by censorship and re-creating a text more open to the target audience unfamiliar with the author's code. Tourniaire provides an interesting and engaging discussion of a contemporary translation question. Her solution, that of translating the text into two languages, French and English, reflecting different translation strategies in each, is creative but somewhat impractical.

Kate Sturge's study of translation practice under the Nazi regime, "A Danger and a Veiled Attack: Translating into Nazi Germany", discusses censorship not as an "internal" constraint on the translator's creativity but as an "external" control limiting what can and cannot be translated. Her study is based on the Bücherkunde, the organ of the literary branch of the Nazi Party's office for political education. She discusses comments on translated texts and translation practice between 1934 and 1944. In this well-documented study, the author illustrates how translation was used both to enhance the image of the Germanic peoples and to denigrate that of others, the French, for example, being portrayed as decadent through a translation of Julien Green. Sturge thus confirms that "translation norms can be traced in terms of attitudes towards the alien in general" (146). External constraints are also the subject of R.A. Magreb's "Ideological Shifts in Cross-Cultural Translation". While the subject is the translation from and into Arabic of primarily ideologically charged texts, the author touches on many issues citing, for example, Lucien Goldman's definition of cultural context. Indeed, Magreb's desire to tie together many cultural and translation issues leads to some confusion. His quotations from The Guardian are, for example, more related to the study of propaganda even if, as he justly claims, the translator could be influenced by this terminology. The author provides numerous interesting examples. However, his conclusion that "different language users, and this includes translators, will assign different meanings to the texts they read" (69) offers nothing new. Alberto Mira's study on contextualizing gay literature, "Pushing the Limits of Faithfulness : A Case for Gay Translation" considers the translation of gay, overtly or not, texts such as The Importance of Being Ernest and The Boys in the $B$ and and the need, or desire, of the translator to emphasize or downplay this aspect. Mira offers some interesting and convincing examples but could have referred more extensively to translation theory. Similarly, Sophia Totzeva's subject, "Realizing Theatrical Potential : The Dramatic Text in Performance and Translation", is of 
tremendous importance and her article would have been strengthened by references to the numerous studies in the field.

As has been illustrated by the above discussion, this is an interesting, albeit somewhat uneven, study of a fundamental translation issue approached from a variety of perspectives and, while it would surely be unreasonable to expect any scholar or volume of scholarly literature to resolve once and for all the "creativity versus fidelity to text" debate, if indeed it should be resolved, this collection of articles illustrates some intriguing approaches to the question. It is worth noting at this point that the authors themselves seem to be in disagreement about the fundamental value of faithfulness to the original and that this, combined with a somewhat troubling blurring of terminology, can lead to confusion for anyone reading the entire collection. Cormac $O$ Cuilleanáin claims, "that translation [...] involves the appropriation of a text as part of a new culture with its own values "(32). In the preceding essay, Emily Salines makes the distinction between "direct" translations and "adaptations and transformations" during which the text is "appropriated" (19). Phyllis Gaffney outlines a case in which "the translator is successful and faithful to the original"(47). Similarly, Jennifer Coates' sweeping claim that "All translators are writers, but not all writers are translators" (91) would not seem to be shared by all the contributors while R.A. Magreb's affirmation that, "Translation means re-writing the source text in the form of the target text" (58) seems in direct contradiction with much of the above. This is, nonetheless, a worthwhile and frequently fascinating collection which includes an index and an extensive bibliography for the entire volume, rather than listings by article. This is useful for those consulting the whole collection and provides a useful tool but could frustrate anyone attempting to locate references for only one article. With this contribution, St. Jerome Publishing remains true to its mission to provide teachers, students, scholars of translation and practising translators with quality scholarship related to issues of current concern.

Jane Koustas

Brock University 